\title{
Supply Chain Integration, Learning, and Agility: Effects on Performance
}

\author{
Habibullah Khan \\ Department of Business Administration, \\ Iqra University, Karachi, Pakistan
}

\author{
Joel D. Wisner \\ Lee Business School, Marketing and International Business Department, \\ University of Nevada, Las Vegas; Las Vegas, Nevada, USA \\ E-mail: joel.wisner@unlv.edu (Corresponding Author)
}

\begin{abstract}
This study examines the interrelationships among supply chain integration, learning, agility and organizational performance. Survey data were collected from 257 publiclyowned companies in Pakistan, and the hypothesized framework was tested using a structural equation model. It was found that supply chain integration had a significant impact on external and internal learning. Additionally, supply chain integration was found to have an insignificant impact on firm performance and supply chain agility. Finally, internal learning was found to have an insignificant impact on supply chain agility, but a significant direct impact on firm performance, while external learning had an insignificant impact on firm performance both directly and indirectly.
\end{abstract}

Keywords: supply chain management, company performance, learning, empirical study, structural equation model

\section{INTRODUCTION}

Customer demand as well as expectations have been rapidly growing since the end of the most recent global recession. Consequently, organizations today are revising their strategic visions and organizational priorities (Sharifi and Zhang, 1999). Organizations now understand that agility is an important survival factor in today's business environment.

Customer demand has also increased the risk of supply chain disruptions due to the diversified nature of supply chain operations. These supply chain disruptions can be harmful to manufacturers, as they can lead to a temporary shut-down of production. Although there are various methods to ensure the continuous flow of products such as increasing safety stocks or use of back-up sourcing, the development of supply chain agility can more effectively reduce the impacts of supply chain disruptions (Tse et al., 2016).

In global markets, organizations face greater uncertainties in meeting specific delivery dates for example, thus requiring a more agile supply chain to consistently deliver effective performance. Flexibility, speed, and quality are the antecedents of agility (Christopher, 2000; Yusuf et $a l ., 2004)$ and organizations must adapt if they expect to survive in the global marketplace. Organizations and their supply chains need to be agile to provide an uninterrupted flow of materials to their global customers. Agility is thus a necessary supply chain tool for any environment where there is volatility in demand. Further, since demand increases cause additional uncertainties, an agile supply chain would be highly effective in such environments.

Cooperation and learning between supply chain members can also help to make supply chains more agile. Learning-oriented organizations are more adaptable and thus higher performing (Slater and Narver, 1995). Firms that are more concerned about learning are more agile and more responsive to uncertainties (Tse et al., 2016). Organizations can learn both internally within the organization and externally from competitors, suppliers and customers.

While many studies have been conducted on the impacts of supply chain integration, agility, and external learning on a firm's performance (see for example Tse et al., 2016; Zhao et al., 2013; and Khan and Pillania, 2008), no study to date has analyzed the impact of internal learning on performance. Additionally, as organizations focus on monitoring and improving their supply chain's performance, they find that supply chain agility cannot be achieved without adequate integration. Supply chain integration is the basic pillar of responsiveness and agility, and improvements can be found through the benchmarking of internal and external best practices. As Gunasekaran et al. (2008) stated, internal and external communication enhances decision making; however to date, no study has looked at the impact of internal learning on performance. This study uses survey data and a structural equation model to examine the impacts of internal and external learning, supply chain integration, and agility on firm performance.

\section{REVIEW OF THE LITERATURE AND HYPOTHESES DEVELOPMENT}

\subsection{Supply Chain Agility}

A good discussion and definition of supply chain agility can be found in Prater et al. (2001). They define supply chain agility as the ability of an organization and its supply chains to adapt swiftly to changing and unpredictable environmental conditions. Firms are thus required to be fast and flexible in their own and their supply chain partners' operations to eliminate these disruptions and ensure the smooth flow of goods and services to end customers 
(Braunscheidel and Suresh, 2009). Initially the path to achieving speed and flexibility was thought to be accomplished through automation. Later, as speed and flexibility were extended to a broader business perspective, the concept of agility in organizations emerged (Christopher, 2000).

Supply chain agility has been found to be positively and directly influenced by the flexibility of the supply chain (Swafford et al., 2006). Previously, researchers gauged supply chain agility as a second order factor and measured it through customer response, joint planning and demand response (Tse et al., 2016). Organizations and their supply chain partners also seek to minimize supply lead times to respond swiftly to demand changes (Christopher and Towill, 2000). Other studies revealed that agile organizations typically launch new products with collaboration from strategic partners (Gehani, 1995; Gligor and Holcomb, 2012; Lummus et al., 2003). As goods quickly flow from one supply chain partner to the next, collaborative planning is required to maintain agility (Lummus et al., 2003). In short, effective joint planning and partnership-building leads to agility (Whitten et al., 2012). Towill (1996) added that reducing lead times can result in added productivity. Since environmental conditions appear to be changing even more dramatically in the $21^{\text {st }}$ century, firms must strive to become ever more agile to survive. Speed and flexibility among supply chain members is thus extremely vital for enhancing performance of the firm (Khan and Pillania, 2008).

Hypothesis 1: Supply chain agility is positively associated with firm performance.

\subsubsection{The mediating role of supply chain agility}

Various studies have shown the direct relationship between supply chain process integration and organizational performance (Flynn et al., 2010; Leuschner et al., 2013). More recently, supply chain integration and external learning have been shown to be indirectly related to firm performance with a mediating role of agility (Tse et al., 2016). Integration of information or resources leads organizations towards flexibility (Leuschner et al., 2013). Additionally, Swafford et al. (2006) said that flexibility, agility and information technology (IT) are all related and create an indirect relationship between integration and performance via a mediating role of supply chain agility. The recent study of Tse et al. (2016) argues that supply chain integration cannot influence the firm's performance without also enhancing supply chain agility.

Research has also been conducted on the direct relationship between learning and firm performance (Noruzy et al., 2013 and Aragón-Corre et al., 2007). Organizational learning was found to be vital for organizational innovation capability and firm performance (Hurley and Hult, 1998). Organizations emphasizing learning enhance their innovation capabilities which ultimately improve organizational performance. Thus, direct and indirect relationships between learning and firm performance were enhanced through innovation and agility (Mone et al., 1998; Gatignon and Xuereb, 1997). Learning can be expanded in management both externally and internally (Slater and Narver, 1995). Tse et al. (2016) found a significant impact of external learning on a firm's performance mediated by supply chain agility. To date, there have been no studies examining the relationship between internal learning and firm performance mediated by supply chain agility. Hypothesis 2a: Supply chain agility mediates the
relationship between supply chain integration and firm
performance.

Hypothesis 2b: Supply chain agility mediates the relationship between external learning and firm performance.

Hypothesis 2c: Supply chain agility mediates the relationship between internal learning and firm performance.

\subsection{Supply Chain Integration}

Supply chain integration is the extent to which the firm integrates with its other supply chain partners to achieve efficient and effective flows of information, products, decisions, money and information with high value, high speed, and low cost (Zhao et al., 2008). Firms are working at integrating their supply chains nowadays to achieve flexibility and speed (Zhao et al., 2008). Integration with supply chain partners also enhances the service quality of the organization (Lee and Padmanabhan, 1997). Supply chain integration has been shown to be positively associated with firm performance (Zhao et al., 2013). Another study though, shows that supply chain integration does not directly influence the organization's performance; instead, performance is influenced indirectly through supply chain agility (Tse et al., 2016). Tse et al. (2016) shows the direct and positive relationship between supply chain integration and supply chain agility. The objective of supply chain integration is to provide maximum value to customers using high speed and low cost with respect to flows of information and materials (Flynn et al., 2010).

Tse et al. (2016) studied the impact of supply chain integration on firm performance. While the direct impact was found to be insignificant, a positive significant impact was found through a mediating supply chain agility variable. Some researchers have reviewed the past studies and found that supply chain integration can also be measured through second-order constructs such as customer integration, internal integration and supplier integration (Flynn et al., 2010). Internal integration is defined as the consistency within the organization (Venkatraman and Prescott, 1990). Flynn et al. (2010) stated that internal integration breaks down functional barriers which are expected to increase firm performance and agility.

Structural contingency theory indicates that customer and supplier integration show the consistency outside the organization and have important parallels with internal integration, which ultimately impact supply chain integration (Flynn et al., 2010). Another researcher has shown that internal integration is an apriori requirement of external integration, which consists of supplier and customer integration (Morash and Clinton, 1998). Thus, external and internal integration are important for manufacturers to understand environmental uncertainties and changes which ultimately impact flexibility and agility (Flynn et al., 2010). Interestingly, one study shows that internal integration positively impacts firm performance while supplier and customer integration do not. Taken together, internal and 
external integration did not influence firm performance (Flynn et al., 2010), which was also the finding of Tse et al. (2016). Finally, successful supply chain integration enables firms to better learn from past mistakes and thus, they tend to focus more on learning (Spekman, Spear and Kamauff, 2002).

Hypothesis 3a: Supply chain integration is positively associated with internal learning

Hypothesis 3b: Supply chain integration is positively associated with external learning

Hypothesis 3c: Supply chain integration is positively associated with supply chain agility

Hypothesis 3d: Supply chain integration is positively associated with firm performance

\subsection{External Learning}

External learning is defined as the acquisition and creation of knowledge gained through joint problem solving with suppliers and customers (Huang et al., 2008). More importantly, an organization that is continuously learning and then processing the knowledge about its external environment is becoming more agile (van Hoek, 2000). Additionally, Tse et al. (2016) found that external learning indirectly influences firm performance through a mediating supply chain agility variable. Firms must learn outside their organizations to leverage new knowledge for enhancing responsiveness, which ultimately becomes the organizations' competitive advantage (Zacharia et al., 2011; Grant, 1996). Additionally, Yu et al., (2013) pointed out that interactive relationships between supply chain partners can enhance organizational learning and thus improve the financial position of the company.

Hypothesis 4a: External learning is positively associated with supply chain agility
Hypothesis 4b: External learning is positively associated with firm performance

\subsection{Internal Learning}

Internal learning refers to employee training and the incorporation of employee suggestions that occur primarily during process or product development (Gerwin and Kolodny, 1992; Hall, 1987; Huang et al., 2008). Baker and Sinkula (1999) found that internal learning leads to increases in market share. Internal learning is also argued to be helpful in the context of agile supply chains (Braunscheidel and Suresh, 2009). As stated in Yu et al. (2013) above, interactive relationships between supply chain partners enhance organizational learning which improves financial performance; thus supply chain partnerships are often the result of collaboration between the organization and its suppliers and customers. To date though, there have been no studies regarding the impact of internal learning on firm performance or supply chain agility. So it is hypothesized that internal learning may help firms enhance their responsiveness and ultimately improve financial performance. Figure 1 shows the proposed structural equation model and associated hypotheses.

Hypothesis 5a: Internal learning is positively
associated with supply chain agility

Hypothesis 5b: Internal learning is positively associated with firm performance

\section{METHODOLOGY}

The research constructs used in this study, notably internal learning, external learning, supply chain agility, supply chain integration and firm performance have been taken from previous studies. The survey instrument (shown in Appendix 1) used a five-point Likert scale. The survey was adapted from previous studies and was validated using several local supply chain experts with more than ten years

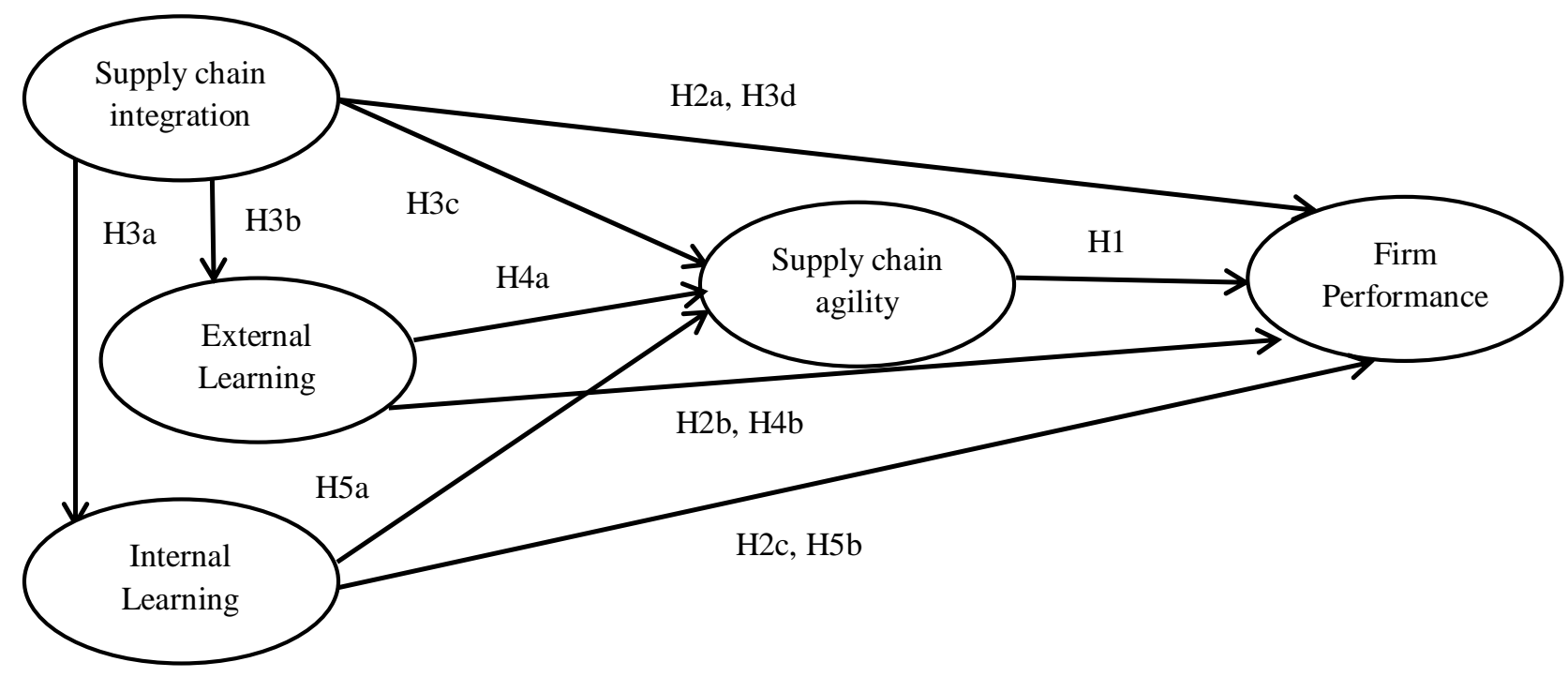

Figure 1 Theoretical Framework 
of experience. The companies selected to receive the survey were registered in the three largest stock exchanges in Pakistan. The relevant supply chain personnel were identified and contacted using their LinkedIn profiles and email addresses. These personnel all held an APICS certification or relevant degree in supply chain management. The survey was emailed in 2017 to 754 supply chain experts in Pakistan. A total of 269 responses were received, with twelve responses found to be unusable due to missing response values. Thus, a total of 257 survey responses (a $34.1 \%$ response rate) were used for this study. This is considered acceptable (Van der Vaart and Van Donk, 2008) given the survey length and topic.

To test the study's hypotheses, AMOS (analysis of a moment structures) was used. AMOS is a statistical software and an SPSS module. It is particularly suited for structural equation modeling, path analysis, and confirmatory factor analysis.

\section{RESULTS}

Table 1 indicates the respondents' demographic information. There were 257 respondents working in seven industries. Over 62 percent of the respondents were in the pharmaceutical, food and beverage, and automobile industries. With regard to administrative position, over 92 percent were directly involved with managing supply chains, while the remaining respondents, executives and company officers, would also be expected to understand supply chain operations and thus the questions on the survey. Most of the respondents' firms (over 70 percent) had over 200 employees, and most of the respondents (over 56 percent) had over seven years of experience in their current positions. It can thus be concluded that all of the respondents were reasonably knowledgeable regarding supply chain operations.

\subsection{Non-Response Bias}

Non-response bias was measured using the method described in Swafford et al., 2006. A t-test for statistically significant differences in the responses was applied to the 50 earliest and 50 latest returned surveys (the late respondents were considered a surrogate for non-respondents, as described in Armstrong and Overton, 1977). No significant differences were found in the responses, thus it was concluded that non-response bias did not significantly affect the study.

\subsection{Common Method Bias}

The data were collected from a single respondent from each organization, therefore the issue of common method bias was examined using Harmon's single-factor test (Harmon, 1967). A factor analysis was performed and the results revealed that 62.7 percent of the total variance was explained with seven variables, having eigenvalues greater than 1.0. The first-factor accounted 24.4 percent of the total variance, indicating that common method bias was not a problem.

\subsection{Reliability and Validity}

Five variables were used in the study - supply chain agility, internal learning, external learning, supply chain integration, and firm performance. Supply chain agility was measured through three second-order factors-joint planning, consumer response and demand response. Confirmatory factor analysis (CFA) was performed on the gathered data to ensure the reliability and validity of the constructs. Chronbach's alpha was used to check for reliability. Based on the coefficient values, the variables tested were concluded to be reliable (Flynn et al., 1994; Malhotra and Grover, 1998; Narasimhan and Jayaram, 1998). The results are shown in Table 2.

After applying CFA on the data, the factor loadings were initially checked, ensuring the values were greater than 0.5. The factor loading of one External Learning item was less than 0.5 ; therefore the item was excluded from the model. Confirmatory factor analysis was used to check the validity of the constructs through convergent and discriminant validity (Brown, 2006). Convergent validity was examined by checking the values of average variance extracted (AVE) for each variable. Researchers suggest that an AVE greater than 0.4 is acceptable (Fornel and Lacker, 1981; O'Leary-Kelly and Vokurka, 1998). Thus, convergent validity exists in the data. Discriminant validity was checked through the values of maximum squared variance (MSV). The results indicated that discriminant validity exists, since the values of AVE are greater than MSV (Sundaram, 2016).

Table 1 Respondent Demographics

\begin{tabular}{|c|c|c|c|c|c|}
\hline Industry & Responses & Percent & Administrative Position & Responses & Percent \\
\hline Pharmaceutical & 59 & 23.0 & Asst. Manager of Supply Chain & 81 & 31.5 \\
\hline Food and beverage & 53 & 20.6 & Manager of Supply Chain & 70 & 27.2 \\
\hline Automobile & 50 & 19.5 & Head of Supply Chain & 46 & 17.8 \\
\hline Textile & 38 & 14.8 & Director of Supply Chain & 40 & 15.5 \\
\hline Chemical and petroleum & 29 & 11.3 & Executive / Officer & 20 & 7.7 \\
\hline Agriculture & 15 & 5.8 & & & \\
\hline \multirow[t]{2}{*}{ Cement } & 13 & 5.1 & Years in current position & & \\
\hline & & & More than 10 years & 87 & 33.8 \\
\hline Number of Employees & & & $8-10$ years & 59 & 22.9 \\
\hline More than 300 & 161 & 62.6 & $4-7$ years & 49 & 19.1 \\
\hline $201-300$ & 20 & 7.8 & $1-3$ years & 54 & 21.0 \\
\hline $101-200$ & 50 & 19.5 & Less than 1 year & 8 & 3.1 \\
\hline $51-100$ & 14 & 5.4 & & & \\
\hline Less than 50 & 12 & 4.7 & & & \\
\hline Total Responses & 257 & & & & \\
\hline
\end{tabular}


Table 2 Reliability and Validity

\begin{tabular}{lcccc}
\hline \multicolumn{1}{c}{ Variables } & $\begin{array}{c}\text { \# of } \\
\text { Items }\end{array}$ & Cronbach's a & AVE & MSV \\
\hline Joint Planning & 3 & .793 & .569 & .192 \\
Demand Response & 3 & .745 & .507 & .185 \\
Consumer & 3 & .739 & .488 & .233 \\
Response & & & & \\
External Learning & 3 & .664 & .404 & .367 \\
Internal Learning & 6 & .799 & .402 & .333 \\
Supply Chain & 3 & .964 & .453 & .367 \\
Integration & & & & \\
Firm Performance & 5 & .816 & .475 & .333 \\
\hline
\end{tabular}

Model fitness was also checked through the values of $\chi^{2} / \mathrm{df}$, comparative fit index (CFI), goodness of fit index (GFI) and the root mean square error of approximation (RMSEA). Table 3 presents the goodness-of-fit data. The value of $\chi^{2} / \mathrm{df}$ was 2.084 , which is within the acceptable range. The values of GFI and CFI were 0.860 and 0.873 respectively, which is also acceptable (Browne and Cudeck, 1993). The value of RMSEA was 0.065 which again indicates good model fit (Byrne, 1998).

Table 3 Goodness-of-fit

\begin{tabular}{lcccc}
\hline & $\mathbf{X}^{2} /$ df & GFI & CFI & RMSEA \\
\hline Values & 2.084 & 0.860 & 0.873 & 0.065 \\
Ideal Value & $<3$ & $\geq 0.9$ & $\geq 0.9$ & $\leq 0.08$ \\
Acceptable & $<5$ & $\geq 0.8$ & $\geq 0.8$ & $\leq 0.08$ \\
Value & & & & \\
\hline
\end{tabular}

\subsection{Analysis of the Structural Model}

Table 4 indicates the standardized item loadings, which are all significant and above 0.4 . Values of 0.4 or greater are considered acceptable (Hair et al., 2010). Mediation was analyzed through a bootstrapping method in AMOS.

\subsubsection{Supply chain agility}

Table 5 presents the measurement model information. Supply chain agility was found to have no significant impact on firm performance. Thus, H1 was not supported. Mishina et al., 2004, found that some resources were not always beneficial for a company, which tends to support the finding of an insignificant relationship between supply chain agility and firm performance. Tse et al., (2016) however, described supply chain agility as the company's distinctive capability, which was argued to enhance firm performance. Obviously, there is some disagreement here with the findings.

\subsubsection{Supply chain integration}

Supply chain integration was found to have a significant and positive relationship with internal learning. A positive significant relationship was also found between learning and supply chain integration in Spekman et al., 2002. The results here provide support for H3a. The results also indicate that supply chain integration had a significant positive impact on external learning, which was supported by Tse et al., 2016. Thus, the results also support H3b. Supply chain integration had an insignificant impact on supply chain agility, thus the study finds no support for $\mathrm{H} 3 \mathrm{c}$. Supply chain integration was found to have an insignificant impact on firm performance, which is consistent with the findings of Tse et al., 2016 and Devaraj et al., 2007.
Table 4 Standardized Item Loadings

\begin{tabular}{|c|c|c|c|}
\hline Variables & Items & $\begin{array}{l}\text { Standardized } \\
\text { Item Loading }\end{array}$ & $\mathrm{p}$-value \\
\hline & DR1 & .69 & *** \\
\hline \multirow{2}{*}{ Demand Response } & DR2 & .79 & $* * *$ \\
\hline & DR3 & .65 & $* * *$ \\
\hline \multirow{4}{*}{$\begin{array}{l}\text { Consumer } \\
\text { Responsiveness }\end{array}$} & CR1 & .71 & $* * *$ \\
\hline & CR2 & .71 & $* * *$ \\
\hline & CR3 & .68 & $* * *$ \\
\hline & JP1 & .75 & $* * *$ \\
\hline \multirow[t]{2}{*}{ Joint Planning } & JP2 & .82 & $* * *$ \\
\hline & JP3 & .69 & $* * *$ \\
\hline \multirow{4}{*}{$\begin{array}{l}\text { Supply chain } \\
\text { integration }\end{array}$} & SCl1 & .61 & $* * *$ \\
\hline & $\mathrm{SCl} 2$ & .80 & *** \\
\hline & $\mathrm{SCl} 3$ & .59 & $* * *$ \\
\hline & EL1 & .54 & *** \\
\hline \multirow[t]{4}{*}{ External Learning } & EL2 & .68 & *** \\
\hline & EL3 & .68 & *** \\
\hline & IL1 & .52 & $* * *$ \\
\hline & IL2 & .49 & $* * *$ \\
\hline \multirow{6}{*}{ Internal Learning } & IL3 & .61 & $* * *$ \\
\hline & IL4 & .60 & $* * *$ \\
\hline & IL5 & .82 & $* * *$ \\
\hline & IL6 & .76 & $* * *$ \\
\hline & FP1 & .70 & $* * *$ \\
\hline & FP2 & .69 & $* * *$ \\
\hline \multirow[t]{3}{*}{ Firm Performance } & FP3 & .73 & $* * *$ \\
\hline & FP4 & .61 & $* * *$ \\
\hline & FP5 & .63 & $* * *$ \\
\hline Note: ${ }^{* *}$ indicates a & cant rela & ip, $p<0.001$ & \\
\hline
\end{tabular}

Table 5 Structural Path Findings

\begin{tabular}{|c|c|c|c|}
\hline Structural Path & B & $\begin{array}{c}\text { P- } \\
\text { value }\end{array}$ & Result \\
\hline \multicolumn{4}{|l|}{ Direct Relationships } \\
\hline $\begin{array}{l}\text { (H1) Supply chain agility } \rightarrow \text { Firm } \\
\text { performance }\end{array}$ & .353 & .381 & Insignificant \\
\hline $\begin{array}{l}\text { (H3a) Supply chain integration } \rightarrow \\
\text { Internal learning }\end{array}$ & .595 & .001 & Significant \\
\hline $\begin{array}{l}\text { (H3b) Supply chain integration } \rightarrow \\
\text { External learning }\end{array}$ & .700 & .001 & Significant \\
\hline $\begin{array}{l}\text { (H3c) Supply chain integration } \rightarrow \\
\text { Supply chain agility }\end{array}$ & .405 & .140 & Insignificant \\
\hline $\begin{array}{l}\text { (H3d) Supply chain integration } \rightarrow \\
\text { Firm performance }\end{array}$ & .418 & .080 & Insignificant \\
\hline $\begin{array}{l}\text { (H4a) External Learning } \rightarrow \text { Supply } \\
\text { chain agility }\end{array}$ & .438 & .115 & Insignificant \\
\hline $\begin{array}{l}\text { (H4b) External Learning } \rightarrow \text { Firm } \\
\text { performance }\end{array}$ & .039 & .919 & Insignificant \\
\hline $\begin{array}{l}\text { (H5a) Internal Learning } \rightarrow \text { Supply } \\
\text { chain agility }\end{array}$ & .094 & .568 & Insignificant \\
\hline $\begin{array}{l}\text { (H5b) Internal Learning } \rightarrow \text { Firm } \\
\text { performance }\end{array}$ & .622 & .022 & Significant \\
\hline \multicolumn{4}{|l|}{ Indirect Relationships } \\
\hline $\begin{array}{l}\text { (H2a) Supply chain integration } \\
\rightarrow \text { Supply chain agility } \rightarrow \text { Firm } \\
\text { performance }\end{array}$ & .668 & .006 & Significant \\
\hline $\begin{array}{l}\text { (H2b) External learning } \rightarrow \text { Supply } \\
\text { chain agility } \rightarrow \text { Firm } \\
\text { performance }\end{array}$ & .155 & .190 & Insignificant \\
\hline $\begin{array}{l}\text { (H2c) Internal learning } \rightarrow \text { Supply } \\
\text { chain agility } \rightarrow \text { Firm } \\
\text { performance }\end{array}$ & .033 & .364 & Insignificant \\
\hline
\end{tabular}

Therefore, in our study, H3d was not supported. Interestingly, several studies (Swink et al., 2007, and 
Koufteros et al., 2005) actually found negative relationships between supply chain integration and firm performance.

\subsubsection{External and internal learning}

External learning was not found to be significantly related to either firm performance or supply chain agility, thus, no support was found for $\mathrm{H} 4 \mathrm{a}$ and $\mathrm{H} 4 \mathrm{~b}$. Internal learning was found to have a significant and positive relationship with firm performance, but not with supply chain agility. Consequently, this study found support for H5b but no support for H5a. The trend of encouraging groups within the firm to share information (which may enhance firm performance) has been shown in Zhang et al., 2005. Additionally, while firms are integrating with their supply chain partners to become flexible, agile, and fast (Zhao et al., 2008 ) the results pointed out that supply chain integration did not necessarily create better agility and performance. Studies have shown that organizational learning is correlated with the development of new knowledge, which enables firms to enhance their innovation capabilities and organizational performance (Hurley and Hult, 1998). Thus, learning may help improve responsiveness which in turn increases firm performance, but this also depends upon other factors such as innovation, new knowledge, trust, and willingness to share information (Christopher, 2000; Zhang et al., 2005; Zhao et al., 2008; Hurley and Hult, 1998).

\subsubsection{Indirect relationships}

The impacts of supply chain integration and internal and external learning on firm performance were analyzed through the mediating role of supply chain agility. The results indicated a significant positive mediating role of supply chain agility between supply chain integration and firm performance, thus supporting H2a. Internal and external learning were also examined using the mediating role of supply chain agility. No indirect impacts of internal and external learning on firm performance were found. Thus, no support was found for $\mathrm{H} 2 \mathrm{~b}$ and $\mathrm{H} 2 \mathrm{c}$. Previous studies also support a mediation role of agility between supply chain integration and firm performance as discussed earlier.

\section{DISCUSSION}

Three of the key findings of the study were that supply chain integration was significantly correlated to both internal and external learning, and that internal learning was found to significantly impact firm performance. When supply chain trading partners share processes and make joint decisions, it creates opportunities for both internal and external learning. Ultimately, as internal learning progresses, firms can better serve customers and improve their performance. It was somewhat surprising that external learning had an insignificant impact on firm performance both directly and indirectly. External learning however, can be beneficial for the company if there is proper integration with supply chain members and most importantly, if there is a commitment of learning, trust, shared visions, shared information and other factors. It can be seen here though, that external and internal learning had mixed results.

This study analyzed the mediating role of supply chain agility on firm performance. Supply chain agility mediated the relationships of supply chain integration, external learning and internal learning with firm performance. Supply chain integration was found to have a significant impact on firm performance when mediated by supply chain agility. This was another key finding of the study. Previous studies have also supported the mediating relationship of supply chain agility with supply chain integration and firm performance.

\section{CONCLUSIONS AND INSIGHTS FOR FURTHER RESEARCH}

Our study found that supply chain integration was significantly correlated to internal and external learning. Further, internal learning was significantly correlated to firm performance. And finally, supply chain integration significantly impacts firm performance when mediated by the firm's agility. Managers wishing to improve firm performance should consider encouraging more communication, information sharing, and training within the firm. Renewed efforts to integrate processes with trading partners should also be considered. As supply chain integration matures, the trading partners become more agile and adapt quickly to any environmental changes. Consequently, firms begin to see better market share and profits.

It can also be surmised that external learning may not always be beneficial for the company, depending upon causal factors and moderators which may impact relationships. As Speakman et al. (2002) indicated, a firm's performance may not necessarily be positively influenced if the firm is integrating processes with supply chain partners. The company's culture and willingness to learn and absorb knowledge from its customers, suppliers, or internally, all impact firm performance. It falls on upper management of the firms to create a learning-oriented environment. Swift and Hwang (2013) suggested that organizations develop trust internally, to create an organizational learning environment. Similarly, Oke et al., (2013) pointed out that the establishment of strategic relationships with supply chain partners will create a learning-oriented environment.

External learning and internal learning can lead to a significant impact on responsiveness and flexibility, but may not always lead to positive impacts on a firm's performance. Organizations need to work on developing new knowledge, innovation, creation of trust and willingness to share ideas and information. As discussed in Calantone et al. (2002), learning-oriented organizations share four factors: a commitment to learning, shared vision, open-mindedness and intraorganizational knowledge sharing. Noruzy et al. (2013) found that organizational performance depends not only on organizational innovation and learning, but also on knowledge management and transformation leadership. Thus, if organizations want to enhance their performance, upper management needs to create a learning-oriented firm. Managers need to remain open minded, share visions among supply chain partners, and share knowledge within the organization.

\subsection{Future Research Directions}

This study found no significant direct relationship between supply chain agility and firm performance, while other studies have at least argued for the existence of this relationship. Obviously, further study is required to test these two variables. While this study looked at the mediating role 
of supply chain agility on firm performance, vis-à-vis supply chain integration, external learning and internal learning, future research could include a comparison of the resourcebased view (RBV), the practice-based view (PBV), and the mixed-based view (MBV) with respect to firm performance. In Wernerfelt (1984), the RBV states that a firm's unique capabilities can enhance the firm's performance and agility. Another more recent study criticized the RBV and proposed the practiced-based view (Bromiley and Rau, 2016). According to Bromiley and Rau, the RBV cannot be used solely to explain a firm's performance, so they proposed the PBV by the inclusion of practices and their impacts on a firm's performance. It is proposed that a new model, the mixed-based view could be used to analyze the impacts of supply chain practices on firm performance-moderators can be included in the MBV to help uncover certain variations in performance. The MBV theory would be beneficial as it would cover both a firm's performance and competitive advantage as dependent variables to analyze more specific results.

Another observation is that this study surveyed only Pakistani companies, thus an obvious extension would be to survey company representatives in other countries such as the U.S. and the U.K. Finally, future studies could assess the role of industry as a controlling variable.

\section{ACKNOWLEDGEMENTS}

The authors would like to thank the anonymous reviewers for their excellent comments and suggestions. They would also like to thank Dr. Nyoman Pujawan for handling the review and editorial processes very well.

\section{REFERENCES}

Aragón-Correa, J., García-Morales, V., and Cordón-Pozo, E. (2007), Leadership and organizational learning's role on innovation and performance: Lessons from Spain, Industrial Marketing Management, 36 3, pp. 349-359.

Armstrong, J., and Overton, T. (1977), Estimating nonresponse bias in mail surveys, Journal of Marketing Research, 14(3), pp. 396-402.

Baker, W., and Sinkula, J. (1999), The synergistic effect of market orientation and learning orientation on organizational performance, Journal of the Academy of Marketing Science, 27(4), pp. 411-427.

Basnet, C. (2013), The measurement of internal supply chain integration, Management Research Review, 36(2), pp. 153-172.

Braunscheidel, M., and Suresh, N. (2009), The organizational antecedents of a firm's supply chain agility for risk mitigation and response, Journal of Operations Management, 27(2), pp. 119-140.

Bromiley, P., and Rau, D. (2016), Operations management and the resource based view: Another view, Journal of Operations Management, 41, pp. 95-106.

Brown, T. (2006), Confirmatory Factor Analysis for Applied Research, Guilford Press, New York, NY.

Browne, M., and Cudeck, R. (1993), Alternative ways of assessing model fit, Sage Focus Editions, 154, pp. 136136.

Byrne, B.M. (1998), Structural Equation Modeling with LISREL, PRELIS and SIMPLIS: Basic Concepts,
Applications and Programming, Lawrence Erlbaum Associates, Mahwah, NJ.

Calantone, R., Cavusgil, S., and Zhao, Y. (2002), Learning orientation, firm innovation capability, and firm performance, Industrial Marketing Management, 31(6), pp. 515-524.

Christopher, M. (2000), The agile supply chain: competing in volatile markets, Industrial Marketing Management, 29(1), pp. 37-44.

Christopher, M., and Towill, D. (2000), Supply chain migration from lean and functional to agile and customized, Supply Chain Management: An International Journal, 5(4), pp. 206-213.

Devaraj, S., Krajewski, L., and Wei, J. (2007), Impact of eBusiness technologies on operational performance: the role of production information integration in the supply chain, Journal of Operations Management, 25(6), pp. 1199-1216.

Ettlie, J. and Pavlou, P. (2006), Technology-based new product development partnerships, Decision Sciences, 37(2), pp. 117-147.

Flynn, B., Huo, B., and Zhao, X. (2010), The impact of supply chain integration on performance: A contingency and configuration approach, Journal of Operations Management, 28(1), pp. 58-71.

Flynn, B., Schroeder, R., and Sakakibara, S. (1994), A framework for quality management research and an associated measurement instrument, Journal of Operations Management, 11(4), pp. 339- 366.

Fornell, C., and Laker, D. (1981), Evaluating structural equation models with unobservable variables and measurement error, Journal of Marketing Research, 18(1), pp. 39-50.

Gatignon, H., and Xuereb, J. (1997), Strategic orientation of the firm and new product performance, Journal of Marketing Research, 34(1), pp. 77-90.

Gerwin, D., and Kolodny, H. (1992), Management of advanced manufacturing technology: Strategy, organization, and innovation, Wiley-Interscience, New York, NY.

Gehani, R. (1995), Time-based management of technology: a taxonomic integration of tactical and strategic roles, International Journal of Operations and Production Management, 15(2), pp. 19-35.

Gligor, D., and Holcomb, M. (2012), Antecedents and consequences of supply chain agility: establishing the link to firm performance, Journal of Business Logistics, 33(4), pp. 295-308.

Grant, R. (1996), Toward a knowledge-based theory of the firm, Strategic Management Journal, 17(S2), pp. 109122.

Hair, J., Anderson, R., Babin, B., and Black, W. (2010), Multivariate Data Analysis: A Global Perspective, Pearson, Upper Saddle River, NJ.

Hall, R. (1987), Organizations: Structures, processes and outcomes, Dow Jones-Irwin, Homewood, IL.

Harmon, H. (1967), Modern Factor Analysis, The University of Chicago Press, Chicago, IL.

Huang, X., Kristal, M., and Schroeder, R. (2008), Linking learning and effective process implementation to mass customization capability, Journal of Operations Management, 26(6), pp. 714-729. 
Hurley, R., and Hult, G. (1998), Innovation, market orientation, and organizational learning: An integration and empirical examination, The Journal of Marketing, 62(3), pp. 42-54.

Khan, K. and Pillania, R. (2008), Strategic sourcing for supply chain agility and firms' performance: A study of Indian manufacturing sector, Management Decision, 46(10), pp. 1508-1530.

Koufteros, X., Vonderembse, M., and Jayaram, J. (2005), Internal and external integration for product development: The contingency effects of uncertainty, equivocality, and platform strategy, Decision Sciences, 36(1), pp. 97-133.

Leuschner, R., Rogers, D., and Charvet, F. (2013), A metaanalysis of supply chain integration and firm performance, Journal of Supply Chain Management, 49(2), pp. 34-57.

Liu, X., Yang, J., Qu, S., Wang, L., Shishime, T., and Bao, C. (2012), Sustainable production practices and determinant factors of green supply chain management of Chinese companies, Business Strategy and the Environment, 21(1), pp. 1-16.

Lummus, R., Duclos, L., and Vokurka, R., (2003), Supply chain flexibility: Building a new model, Global Journal of Flexible Systems Management, 4(4), pp. 113.

Malhotra, M., and Grover, V. (1998), An assessment of survey research in POM: From constructs to theory, Journal of Operations Management, 16(4), pp. 407425.

Marquez, A., Bianchi, C., Gupta, J. (2004), Operational and financial effectiveness of e-collaboration tools in supply chain integration, European Journal of Operational Research, 159(2), pp. 348-363.

Merschmann, U. and Thonemann, U. (2011), Supply chain flexibility, uncertainty and firm performance: An empirical analysis of German manufacturing firms, International Journal of Production Economics, 130(1), pp. 43-53.

Mishina, Y., Pollock, T., and Porac, J. (2004), Are more resources always better for growth? Resource stickiness in market and product expansion, Strategic Management Journal, 25(12), pp. 1179-1197.

Mone, M., McKinley, W., and Barker, V. (1998), Organizational decline and innovation: A contingency framework, Academy of Management Review, 23(1), pp. 115-132.

Narasimhan, R., Jayaram, J. (1998), Causal linkages in supply chain management: An exploratory study of North American manufacturing firms, Decision Sciences, 29(3), pp. 579-605.

Noruzy, A., Dalfard, V., Azhdari, B., Nazari-Shirkouhi, S., and Rezazadeh, A. (2013), Relations between transformational leadership, organizational learning, knowledge management, organizational innovation, and organizational performance: An empirical investigation of manufacturing firms, The International Journal of Advanced Manufacturing Technology, 64(5/8), pp. 1073-1085.

Oke, A., Prajogo, D., and Jayaram, J. (2013), Strengthening the innovation chain: The role of internal innovation climate and strategic relationships with supply chain partners, Journal of Supply Chain Management, 49(4), pp. 43-58.

O'Leary-Kelly, S., and Vokurka, R. (1998), The empirical assessment of construct validity, Journal of Operations Management, 16(4), pp. 387-405.

Prater, E., Biehl, M., and Smith, M. (2001), International supply chain agility: Tradeoffs between flexibility and uncertainty, International Journal of Operations and Production Management, 21(5/6), pp.823-839.

Schroeder, R., Bates, K., and Junttila, M., (2002), A resource-based view of manufacturing strategy and the relationship to manufacturing performance, Strategic Management Journal, 23(1), pp. 105-117.

Shah, R., Goldstein, S., and Ward, P. (2002), Aligning supply chain management characteristics and interorganizational information system types: An exploratory study, IEEE Transactions on Engineering Management, 49(3), pp. 282-292.

Sharifi, H., and Zhang, Z. (1999), A methodology for achieving agility in manufacturing organisations: An introduction, International Journal of Production Economics, 62(1), pp. 7-22.

Slater, S., and Narver, J. (1995), Market orientation and the learning organization, The Journal of Marketing, 59(3), pp. 63-74.

Spekman, R., Spear, J., and Kamauff, J. (2002), Supply chain competency: Learning as a key component, Supply Chain Management: An International Journal, 7(1), pp. 41-55.

Sundaram, A. (2016), A painstaking exploration on the influence of perceived benefits towards training on training and development in Indian IT/ITES industry, Journal of Internet Banking and Commerce, 21(2), pp. 1.

Swafford, P., Ghosh, S., and Murthy, N. (2006), The antecedents of supply chain agility of a firm: Scale development and model testing, Journal of Operations Management, 24(2), pp. 170-188.

Swift, P., and Hwang, A. (2013), The impact of affective and cognitive trust on knowledge sharing and organizational learning, The Learning Organization, 20(1), pp. 20-37.

Swink, M., Narasimhan, R., and Wang, C. (2007), Managing beyond the factory walls: Effects of four types of strategic integration on manufacturing plant performance, Journal of Operations Management, 25(1), pp. 148-164.

Towill, D. (1996), Time compression and supply chain management: A guided tour, Supply Chain Management: An International Journal, 1(1), pp. 1527.

Tse, Y., Zhang, M., Akhtar, P., and MacBryde, J. (2016), Embracing supply chain agility: An investigation in the electronics industry, Supply Chain Management: An International Journal, 21(1), pp. 140-156.

Van der Vaart, T. and van Donk, D. (2008), A critical review of survey-based research in supply chain integration, International Journal of Production Economics, 111(1), pp. 42-55.

van Hoek, R., 2000, From reversed logistics to green supply chains, Logistics Solutions 2, pp. 28-33. 
Wernerfelt, B. (1984), A resource-based view of the firm, Strategic Management Journal, 5(2), pp. 171180.

Whitten, G., Green Jr, K., and Zelbst, P. (2012), Triple-A supply chain performance, International Journal of Operations and Production Management, 32(1), pp. 28-48.

Yu, W., Jacobs, M., Salisbury, W. and Enns, H. (2013), The effects of supply chain integration on customer satisfaction and financial performance: An organizational learning perspective, International Journal of Production Economics, 146(1), pp. 346358.

Yusuf, Y., Gunasekaran, A., Adeleye, E., and Sivayoganathan, K. (2004), Agile supply chain capabilities: Determinants of competitive objectives, European Journal of Operational Research, 159(2), pp. 379-392.

Zacharia, Z., Nix, N. and Lusch, R. (2011), Capabilities that enhance outcomes of an episodic supply chain collaboration, Journal of Operations Management, 29(6), pp. 591-603.

Zhang, J., Dawes, S., and Sarkis, J. (2005), Exploring stakeholders' expectations of the benefits and barriers of e-government knowledge sharing, Journal of Enterprise Information Management, 18(5), pp. 548567.

Zhang, M., and Huo, B. (2013), The impact of dependence and trust on supply chain integration, International Journal of Physical Distribution and Logistics Management, 43(7), pp. 544-563.

Zhao, X., Huo, B., Flynn, B., and Yeung, J. (2008), The impact of power and relationship commitment on the integration between manufacturers and customers in a supply chain, Journal of Operations Management, 26(3), pp. 368-388.

Zhao, L., Huo, B., Sun, L., and Zhao, X. (2013), The impact of supply chain risk on supply chain integration and company performance: A global investigation, Supply Chain Management: An International Journal, 18(2), pp. 115-131.

\section{APPENDIX 1: SURVEY INSTRUMENT}

\begin{tabular}{|c|c|c|c|c|c|}
\hline $\begin{array}{l}\text { Supply Chain Survey } \\
\text { Please indicate your agreement with the following statements. } \\
\text { Note: } S D=\text { strongly disagree, } D=\text { disagree, } N=\text { neutral, } A=\text { =agree, } S A=\text { strongly agree }\end{array}$ & SD & D & $\mathbf{N}$ & A & SA \\
\hline \multicolumn{6}{|l|}{ Demand Response ${ }^{1}$} \\
\hline $\begin{array}{l}\text { 1. Our supply chain is able to leverage the competencies of our partners to respond } \\
\text { to market demands }\end{array}$ & & & & & \\
\hline 2. Our supply chain is capable of forecasting market demand & & & & & \\
\hline 3. Our supply chain is capable of responding to real market demand & & & & & \\
\hline \multicolumn{6}{|l|}{ Consumer Responsiveness ${ }^{2}$} \\
\hline 1. Our products are customized rather than standardized & & & & & \\
\hline $\begin{array}{l}\text { 2. Our supply chain utilizes postponement strategies to enable customization of } \\
\text { products / services }\end{array}$ & & & & & \\
\hline 3. We strive to increase the level of customization & & & & & \\
\hline \multicolumn{6}{|l|}{ Joint Planning $^{3}$} \\
\hline 1. Joint planning with suppliers is important in purchasing & & & & & \\
\hline 2. Joint planning with suppliers is important in production & & & & & \\
\hline 3. Joint planning with customers is important in logistics & & & & & \\
\hline \multicolumn{6}{|l|}{ Supply Chain Integration ${ }^{4}$} \\
\hline $\begin{array}{l}\text { 1. We work with our suppliers to seaminglessly integrate our inter-firm processes } \\
\text { (eg, order placement) }\end{array}$ & & & & & \\
\hline $\begin{array}{l}\text { 2. Our supply chain uses rapid response initiatives (eg, continuous replenishment or } \\
\text { Vendor Managed Inventory) }\end{array}$ & & & & & \\
\hline 3. We strive to establish long-term relationships with our supply chain members & & & & & \\
\hline \multicolumn{6}{|l|}{ External Learning ${ }^{5}$} \\
\hline $\begin{array}{l}\text { 1. We often learn from other companies about their management practices to } \\
\text { improve our own }\end{array}$ & & & & & \\
\hline $\begin{array}{l}\text { 2. We maintain close communication with suppliers about quality considerations and } \\
\text { design changes }\end{array}$ & & & & & \\
\hline 3. Our customers give us feedback on quality and delivery performance & & & & & \\
\hline 4. $\quad$ Our customers are actively involved in our product design process & & & & & \\
\hline \multicolumn{6}{|l|}{ Internal learning ${ }^{6}$} \\
\hline $\begin{array}{l}\text { 1. We have adequate internal routines to analyze the knowledge obtained from our } \\
\text { external partner }\end{array}$ & & & & & \\
\hline $\begin{array}{l}\text { 2. We successfully integrate existing knowledge with new knowledge acquired from } \\
\text { our external partner }\end{array}$ & & & & & \\
\hline
\end{tabular}




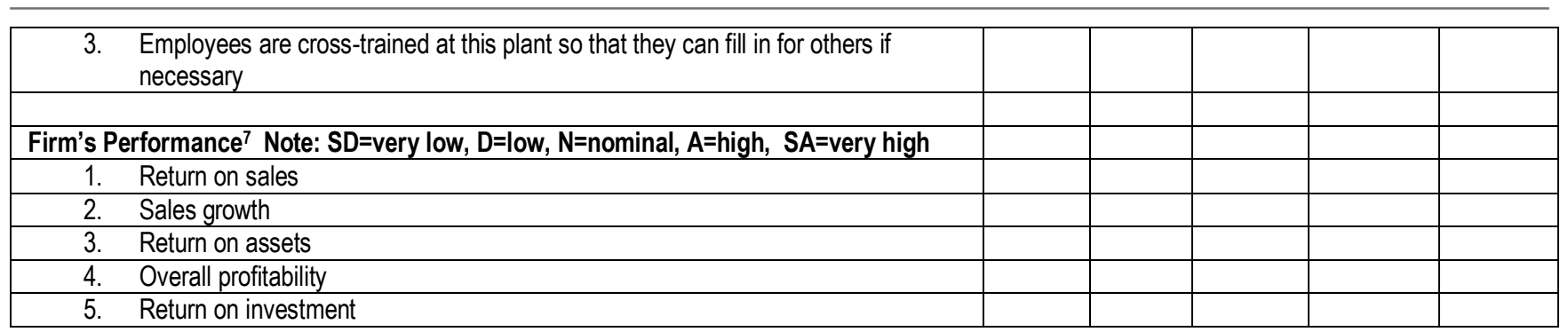

1 (adapted from Christopher, 2000; van Hoek et al., 2001; Braunscheidel and Suresh, 2009)

2 (adapted from Swafford, 2003; Braunscheidel and Suresh, 2009)

${ }^{3}$ (adapted from Braunscheidel and Suresh, 2009)

4 (adapted from van Hoek et al., 2001; Shah et al., 2002; Braunscheidel and Suresh, 2009)

5 (adapted from Schroeder et al., 2002; Liu et al., 2012)

${ }^{6}$ (adapted from Ettlie and Pavlau, 2006; Huang et al., 2008)

7 (adapted from Merschmann and Thonemann, 2011; Calantone et al., 2002)

Habibullah Khan is a Lecturer at Iqra University, Pakistan. He has a Master's degree in Supply Chain Management from Iqra University and is planning to begin his PhD in the U.S. He can be reached at hu.khan4@gmail.com.

Joel D. Wisner received his Ph.D. in Supply Chain Management from Arizona State University in 1991. His textbook, Principles of Supply Chain Management, Cengage, is a leading global textbook in supply chain management. Dr. Wisner has also published Operations Management, Sage, and over 50 papers on a variety of purchasing, operations, and transportation topics in top-level journals. He can be reached at joel.wisner@unlv.edu. 